\title{
CEP Member
}

National Cancer Institute

\section{Source}

National Cancer Institute. CEP Member. NCI Thesaurus. Code C51808.

A member of the multidisciplinary Concept Evaluation Panel (CEP) org anized under the leadership of the $\mathrm{NCI}$ Cancer Therapy Evaluation Program to evaluate Phase III clinical trial proposals. Membership includes $\mathrm{NCl}$ staff and representatives of $\mathrm{NCl}$-sponsored Cooperative Groups and Cancer Centers, as well as other sources. Two-thirds of the CEP members (clinicians, basic scientists, statisticians, other oncology professionals, and patient advocates) are not affiliated with $\mathrm{NCl}$. 